\title{
SETUP ANALYSIS: COMBINING SMED WITH OTHER TOOLS
}

\author{
Dorota Stadnicka \\ Rzeszow University of Technology, Faculty of Mechanical Engineering and Aeronautics, Poland
}

\section{Corresponding author:}

Dorota Stadnicka

Rzeszow University of Technology

Faculty of Mechanical Engineering and Aeronautics

Powstańców Warszawy 12, 35-959 Rzeszów, Poland

phone: +48 17 865-14-52

e-mail: dorota.stadnicka@prz.edu.pl

Received: 12 October 2014

Accepted: 9 December 2014

\begin{abstract}
The purpose of this paper is to propose the methodology for the setup analysis, which can be implemented mainly in small and medium enterprises which are not convinced to implement the setups development. The methodology was developed after the research which determined the problem. Companies still have difficulties with a long setup time. Many of them do nothing to decrease this time. A long setup is not a sufficient reason for companies to undertake any actions towards the setup time reduction. To encourage companies to implement SMED it is essential to make some analyses of changeovers in order to discover problems. The methodology proposed can really encourage the management to take a decision about the SMED implementation, and that was verified in a production company. The setup analysis methodology is made up of seven steps. Four of them concern a setups analysis in a chosen area of a company, such as a work stand which is a bottleneck with many setups. The goal is to convince the management to begin actions concerning the setups improvement. The last three steps are related to a certain setup and, there, the goal is to reduce a setup time and the risk of problems which can appear during the setup. In this paper, the tools such as SMED, Pareto analysis, statistical analysis, FMEA and other were used.

Implementing the proposed methodology can change the attitude of the management. The risk analysis helps to prevent problems with a setup. This methodology can be used in production companies which make changeovers, particularly, in the companies where SMED hasn't been introduced yet.
\end{abstract}

KEYWORDS

setup, SMED, FMEA, analysis.

\section{Introduction}

Setups are necessary to follow production processes of various products types. Typically, in production processes of different products, various tools and equipment are also used. Developing setup processes is even more important now when a product range in many companies is growing and, at the same time, the size of production series is reduced. Each setup consumes time and it doesn't add value to a product. That is why, each company should aim to reduce a setup time to a very small amount of time.

Unfortunately, the problem of machines setup improvement is not considered in many companies at all. The problem seems to be for them not important from the business point of view. The issues concerning a setup process are the domain of operators who do the setup in the best possible way they can. No one contests if a setup process doesn't influence the product and production process quality.

This paper presents the results of the study conducted in production companies where setups are realized. The results indicate that it is necessary to analyze why the companies don't undertake any improvement actions concerning setups. Two questions arise:

- How to convince companies that the setup development is important?

- What to do during the setup process development? 
The proposal of a setup analysis is presented in this work. Rules, methods and tools which can be used in such analysis are indicated. The case study, in which the proposed steps were implemented, is also shown on the basis of one work stand in a production company. For the reason data gathered in [1] were used.

The steps of the analysis are recommended to apply, particularly in small and medium companies which haven't made the setups development yet and which don't possess many financial resources on highly developed tools proposed in the literature.

\section{Development of setup shortening concept}

In the concept of Toyota Production System, which is well known and implemented in many factories, it is required to eliminate wastes in a company. Among others, the waste of time is specified. One of the biggest time consumers in a production line is a setup process, particularly when the production in small series or one piece production are mentioned. Each setup is waste because it doesn't add any value. Unfortunately, it is necessary to run production. The time consumed for a setup could be spent on production [2]. If the setup time is shorter the production line is more flexible, and a company can respond easier to the changing requirements of customers [3]. Companies really need to improve changeovers and this is one of the best manufacturing practices [4].

The setup development can be done with the use of a well-known method called SMED. This method was developed by Shigeo Shingo in 1969. Then, he used the method for the first time to shorten a setup time of the press in Honsha, one of Toyota plants. Using this method brought unexpectedly good results in a form of a much shorter setup time. By the means of this method, Shigeo Shingo was able to increase productivity up to $40 \%$ in Heavy Industry in Hiroshima. The time of building a ship was shortened from 4 to 2 months [5].

SMED is one of the lean manufacturing methods [6]. For many years the SMED method has been used with success. In the literature, many examples of good results can be found. For example, in the work [7] after implementing SMED the authors achieved the cost reduction equal to $2 \%$ of the company's sales volume.

Many examples of using the SMED method can be found in various industries e.g. in casting machines changeover [8], in pharmaceutics industry [9], in a metallurgical sector [10], in the setup time re- duction of a press used in the evaporator plates machining [11]. In the work [12] the percentage of the changeover time reduction in various industries is presented.

SMED can be used in reducing the changeover time by focusing on the maintenance activity [13].

In the works $[14,15]$ the authors indicate that at the very stage of a tooling design one should think about a setup time. Van Goubergen and Van Landeghem, in their work, present rules for a better equipment design [14]. It is also necessary to remember about tooling regeneration in a maintenance process in order to keep everything ready to use in a setup [16].

In the work [17] the author looks for the relation between SMED and the equipment design in the automotive industry using $C_{p k}$ analysis.

The concept of the SMED method was enriched by other methods and techniques such as FMEA method [18] or creative thinking techniques [19]. Van Goubergen developed SMED and supported a broadened methodology of TransMeth for Set-Up Reduction, which is based on changes [20]. Some authors recommend using computer systems. For example in the work [21] the authors propose to integrate SMED and MTM analysis to develop standard documents in MTM-UAS codes in order to sustain the results of SMED. Furthermore, in the work [22] the authors extended SMED by a computerized information system and they used computerized tools such as barcode readers or wireless terminals. A setup time is also important for a scheduling process [12]. It is possible to minimize a setup time using such a planning system which generates a right tasks sequence $[23,24]$.

It can be concluded from the literature review that the necessity of setup reduction was recognized a long time ago. The SMED method is also well known in industry. SMED was enriched with different methods, techniques and computer systems. However, the question is: is it enough to encourage a company to use the SMED method for setup reduction and are the advanced methods proposed in the literature easy enough to use by small and medium companies.

In this paper, the author tries to answer the question of what kind of analysis the companies will be willing to use in the Polish environment.

On the basis of the literature review, it can be said that definitely many companies have implemented SMED and have performed various activities to improve a setup process. However, as the author's experience shows, many Polish companies do nothing to improve a setup process. 
That is why, in the first place, the surveys were conducted. They were done not to draw out conclusions concerning the whole population but only to recognize the problem.

\section{Survey in companies}

\section{Necessity of survey}

For years it has been known that a setup process is important especially for production flexibility. For many years companies have taken actions to decrease a setup time. The issue concerning the setup process seems to be well recognized, thus each company can take improvement actions. What's more, the SMED method exists and describes step by step what to do to decrease a setup time. However, according the author, there are companies which do nothing about the setups improvement. They don't conduct any analyses and they sometimes don't even register the setup times or they don't use the information about the setup time in a planning process. The goal of the survey was to answer the question if these assumptions are correct as well as to obtain the data for a further analysis.

\section{Goal and research methodology}

The goal of the survey was to receive information about the setup processes realization in companies. To obtain the goal the survey was conducted. It was addressed to operators from 88 randomly chosen companies from the Podkarpacie region in Poland, They were asked to answer questions concerning a setup process. The questionnaires were given to them personally or sent by e-mail. 29 operators gave back the fulfilled questionnaires. That covers $32.95 \%$.

The questionnaire consists of 10 questions concerning the following issues: Setup rate, Setup time, Accessibility of devices and tools necessary for performing a setup, Source of operator's knowledge about a setup process, Repeatability of a setup process, Setup standardization, Setup matrix, Standard time for a setup, Setup process improvement.

The percentage of the companies that participated in the survey, in respect of their size, is as follows: micro $-8 \%$, small $-25 \%$, medium $-39 \%$ and large $-28 \%$. All these companies possess production machines (manual, semi-automatic or CNC machines) which need changeovers.

\section{Research hypothesis}

Before the survey started, the following assumption was made:

Undertaking actions concerning the setup process improvement depends on how often the setup is realized and how much time it takes (formula (1)),

$$
y 1=f(x 1, x 2),
$$

where $y 1$ - undertaking improvement actions concerning a setup, $x 1$ - a setup rate, $x 2$ - average time of a setup.

It seems obvious that if setups take much time, or if they are frequent, the companies will take whichever actions to decrease the setup time.

On the basis of the data gathered in the survey, the author wanted to confirm or to reject the assumption.

\section{Survey results and data analysis}

The survey results are presented in Figs. 1-8. Based on the survey results, it can be said that in $44 \%$ of the cases at least a few setups a day are realized (Fig. 1). Additionally, there are setups which last for more than one hour (Fig. 2). In $33 \%$ of the cases an operator, in order to carry out a setup, has to bring to the work stand from one or more other places the needed devices and tools (Fig. 3).

\section{How often setups are made?}

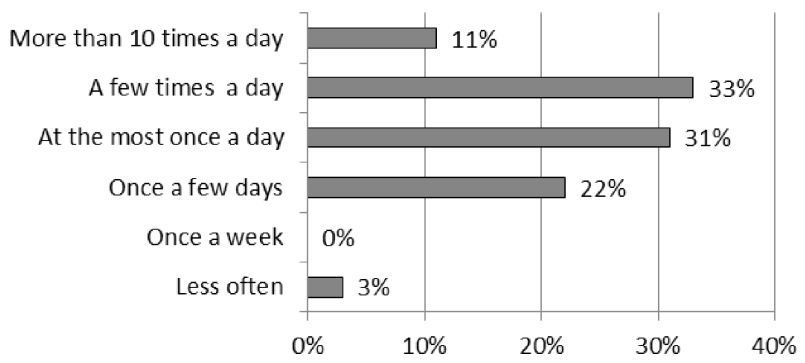

Fig. 1. Setup rate.

\section{How long does it take to do setup, average?}

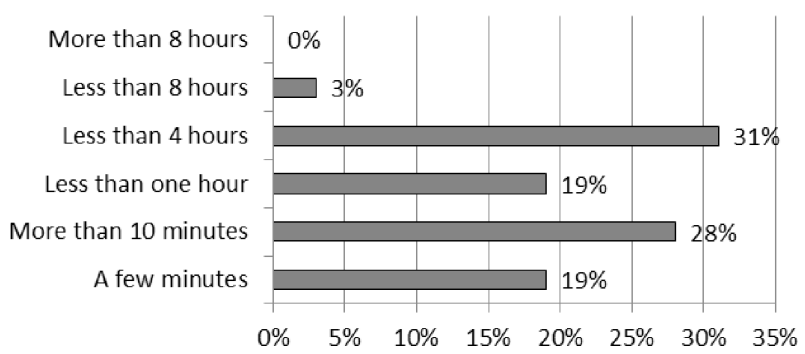

Fig. 2. Setup time. 
Does an operator have all the devices and tools needed in a setup proces on the work stand?

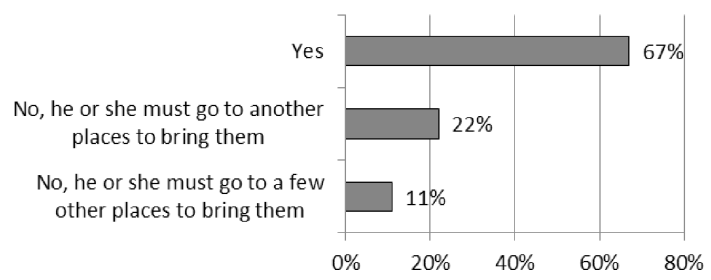

Fig. 3. Accessibility of devices and tools needed in setups.

\section{How an operator knows how to perform setup process?}

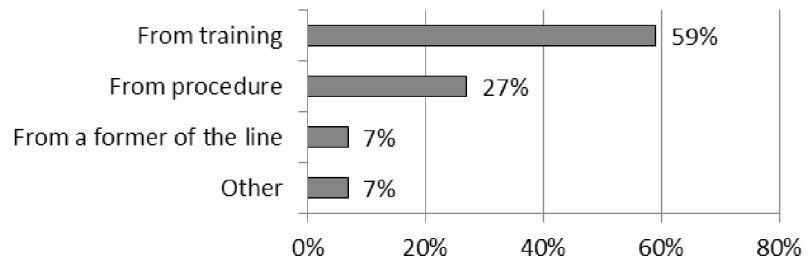

Fig. 4. Source of an operator's knowledge about the setup process.

\section{Does a procedure with information how to perform setup process exist?}

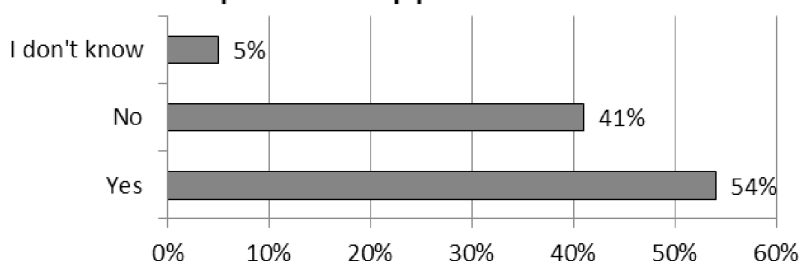

Fig. 5. Setup process standardization.

\section{Does for your work stand setup matrix exist?}

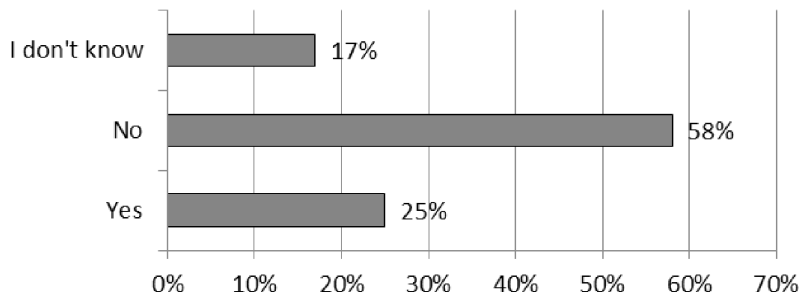

Fig. 6. Setup matrix.

\section{Are time standards for setups settled?}

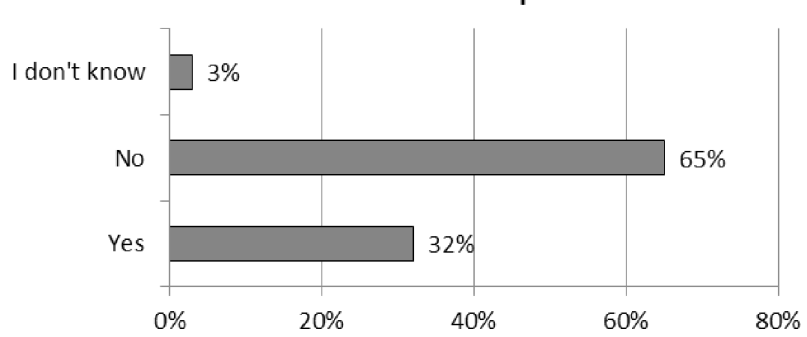

Fig. 7. Time standard for the setup process.

\section{Does your company do something to decrease} setup time?

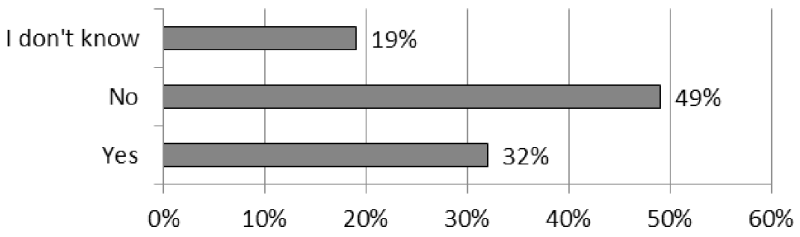

Fig. 8. Undertaking actions towards the setup process improving.

In $50 \%$ of the cases an operator realizes the same type of setups according to the settled rules and, only in $27 \%$ of the cases, an operator follows a procedure in a setup process (Fig. 4). In $50 \%$ of cases an operator performs the setup process in the way more convenient for him without any settled rules. The setup procedure is available only in $53 \%$ of the cases (Fig. 5). Moreover, only in $25 \%$ of the cases a setup matrix exists (Fig. 6). In $31 \%$ of the questionnaires the operators answered that time standards for setup processes are established (Fig. 7). Besides, only in $33 \%$ of the cases some improvement actions are taken in order to reduce the setup time (Fig. 8). These are done by a setup process analysis, workshops or the SMED method implementation.

In a few cases 'I don't know' answers appeared. They regarded the questions concerning the setup process standardization, a setup matrix and improvement actions. That could mean that the operators are not informed properly about the rules and procedures existing in the company, and they are probably neither involved in improvement actions nor informed about them.

Statistical analyses were made with the obtained results in order to assess the correctness of a formulated hypothesis. $C h i^{2}$ test was made. On the basis of the obtained $P$-value, the influence $(+)$ or the lack of influence $(-)$ were identified. In Table 1 the results of the analysis are presented.

\section{Table 1}

The results of the assessment of a setup rate and average time of setups influence on undertaking improving actions concerning a setup process.

\begin{tabular}{l|c}
\hline Hypothesis & $P$-value \\
\hline $\begin{array}{l}\text { For undertaking improving actions there is } \\
\text { no difference if setups are made at least } \\
\text { once a day and if setups are made less than } \\
\text { once a day }\end{array}$ & 0.269 \\
\hline $\begin{array}{l}\text { For undertaking improving actions there is } \\
\text { no difference if setups take less than } 1 \text { hour } \\
\text { and if setups take more than } 1 \text { hour }\end{array}$ & 0.525 \\
\hline
\end{tabular}

On the basis of Table 1 it can be concluded that in the surveyed companies the average time of a set- 
up process and a rate of setups have no significant influence on the decision making about undertaking improving actions concerning a setup process.

It means that other factors exist and have impact on the decision. These factors were not identified in the survey.

\section{Conclusions from the survey}

None of the factors, which were primarily recognized as having significant influence on the fact of undertaking actions concerning the setup process improvement, are really significant. It means that either the number of setups or the setup time don't have influence on the decision about taking the setup improvement actions. It indicates that other factors must influence such a decision.

These possibly are:

- the level of the top management engagement in the improvement process in the company,

- the level of employees' engagement in the improvement process in the company,

- the incentive system encouraging employees to take improvement actions,

- financial resources assigned to the improvement process,

- the lack of knowledge concerning the methodology of a setup analysis in the company.

On the basis of the conducted survey, it can be said that $47 \%$ of the studied companies have never taken any actions concerning the setup time reduction.

One of the reasons for this situation can be the lack of the top management conviction about advantages which the improvement of a setup process could bring. Another reason can be the lack of knowledge about the setup analysis methodology as well as of the possibilities of a setup process shortening. Although the SMED method has been known for many years, there are still companies which don't know this method. For this reason, it is justified to present the methodology of conducting a setup analysis together with indicating the rules, methods and tools which can help to conduct such an analysis. In this work, such a methodology is proposed. Furthermore, it is implemented in a production company in the setup processes analyzing.

\section{Proposed methodology for setup analysis}

In many cases companies don't take any improvement actions in order to reduce the setup time, not only because they don't know the SMED method but also because they are not convinced that it is a problem worth dealing with. That is why, the author proposes to conduct an analysis to obtain the data which can convince the management to start the setup improvement. Managers sometimes think that it is a loss of time to analyze setups. They force people to work faster or longer to carry out tasks in the settled time while they should think how to eliminate a waste of time.

In this paper, the author proposes to use certain rules, methods and tools in the analysis of setup processes. The proposed methodology is easy to implement in any company. The tree of a setup analysis is presented in Fig. 9, and the steps for the identification and elimination of waste in Table 2. The final goal of such an analysis should be the identification and elimination of waste as well as the improvement of a setup process.

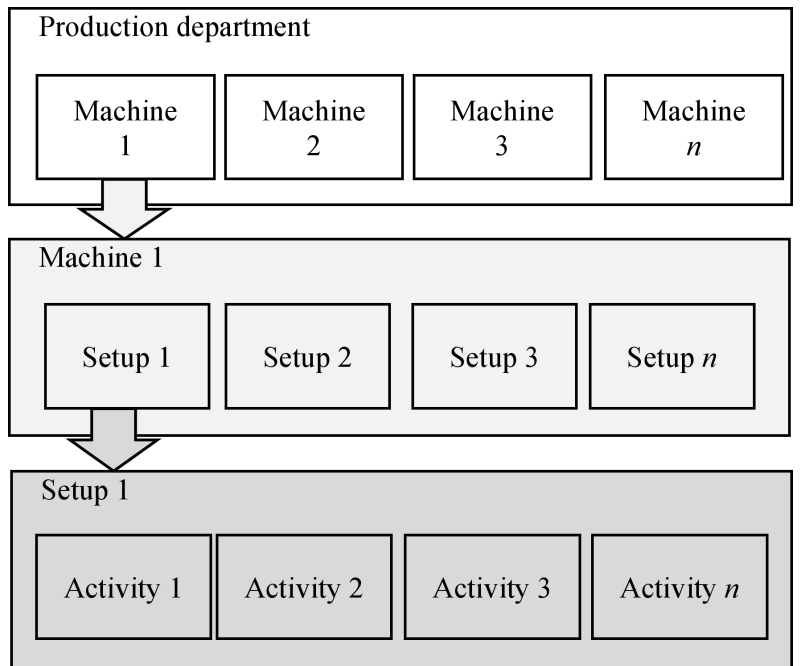

Fig. 9. Tree of a setup analysis.

First of all, in order to convince the management to start a setup process improvement, the data should be gathered and analyzed. That is why, based on the data, the most important setups for time saving should be analyzed. 
Table 2

Proposal of steps for identification and elimination of waste in a setup process.

\begin{tabular}{|c|c|}
\hline Goal: & Chosing a setup for a further analysis \\
\hline Tools: & Pictogram, Pareto-Lorenz analysis \\
\hline Advantages: & $\begin{array}{l}\text { Visual information about the lay-out of work stands with setups. Information } \\
\text { about the distance between the work stands, particularly, if the same devices } \\
\text { and tools are used in setups. Information about work stands on which a setup } \\
\text { problem is the largest. }\end{array}$ \\
\hline \multicolumn{2}{|r|}{ Step 2. Observation and analysis of work on a certain work stand } \\
\hline Goal: & Identification of activities which are realized by an operator on the work stand \\
\hline Tools: & $5 \mathrm{x}$ Why? for the work stand \\
\hline Advantages: & $\begin{array}{l}\text { Identified activities providing general information on: which are value-adding, } \\
\text { which are non-value-adding, which are non-value-adding but necessary, which } \\
\text { can be moved to other work stands }\end{array}$ \\
\hline \multicolumn{2}{|r|}{ Step 3. Gathering data concerning setups on the work stand } \\
\hline Goal: & Identification of setup types and measuring real setup times \\
\hline Tools: & Control sheets, Time study \\
\hline Advantages: & Obtaining real data \\
\hline \multicolumn{2}{|r|}{ Step 4. General analysis of all setups and choosing the first setup to analyze } \\
\hline Goal: & $\begin{array}{l}\text { Comparison of real setup time with planned setup time. Identification of a } \\
\text { setup with the longest time. Identification of the most frequently undertaken } \\
\text { setups }\end{array}$ \\
\hline Tools: & $\begin{array}{l}\text { Pareto-Lorenz diagram, Histogram, Bar chart, Statistical analysis, Dotplot, } \\
\text { Boxplot, decision support model for a setup selection }\end{array}$ \\
\hline Advantages: & Obtaining the information on the real problems with setups \\
\hline \multicolumn{2}{|r|}{ Step 5. Analysis of the chosen setup } \\
\hline Goal: & Shortening the setup time \\
\hline Tools: & $\begin{array}{l}\text { Team work, SMED, Spaghetti diagram, Brainstorming, Benchmarking, Visu- } \\
\text { alization, } 5 \mathrm{~S}\end{array}$ \\
\hline Advantages: & Increasing the effective working time \\
\hline \multicolumn{2}{|r|}{ Step 6. Risk analysis } \\
\hline Goal: & Identification of the risks to prevent problems during the setup \\
\hline Tools: & FMEA \\
\hline Advantages: & Possibility of problems prevention \\
\hline \multicolumn{2}{|r|}{ Step 7. Setup standardization } \\
\hline Goal: & Repeatability of a setup process \\
\hline Tools: & Standardization \\
\hline Advantages: & The same amount of setup time in every case \\
\hline
\end{tabular}

\section{Step 1. Identifying work stands with setups and choosing a work stand to analyze}

This step concerns data gathering. In this step such a tool as a pictogram can be used. The pictogram (Fig. 10) can be used to present the information concerning a number of work stands, symbols of setups and the flow of tools used in various setups.

After that, one machine should be chosen in order to carry out the further analysis. We can also conduct Pareto-Lorenz analysis to identify the longest or the most frequent setups assuming that such data already exist in the company.

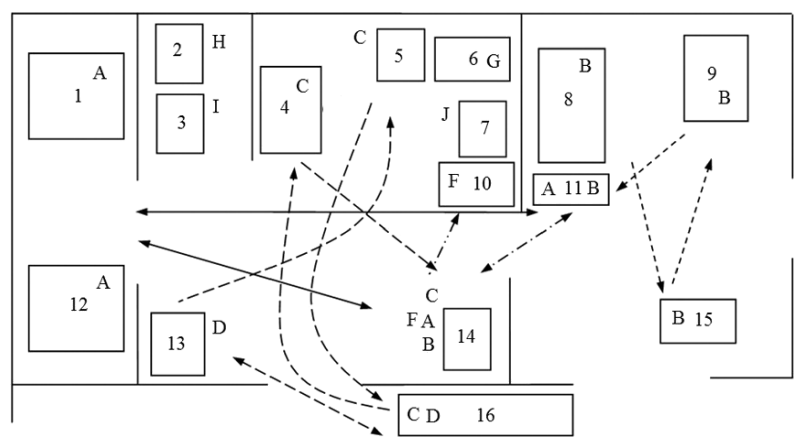

Fig. 10. Example of a pictogram with the data concerning setups processes; 1-16 - a number of work stands, A-J - a setup symbol. 


\section{Step 2. Observation and analysis of work on a certain work stand \\ In the second step we conduct a detailed analy- sis of the activities performed on the chosen work stand. We can use $5 \mathrm{x}$ Why? analysis to do it. During the analysis various questions are asked. They con- cern the purpose of the work stand, the location of the work stand, the sequences realized on this work stand, people working on the work stand and the means used at work. The analysis can help to iden- tify and understand general problems on the work stand as well as to help in the further analysis.}

\section{Step 3. Gathering data concerning setups} on the work stand

This step concerns gathering the detailed data on the setups realized on the chosen work stand, such as: types of setups or setups duration. In order to gather the data, control sheets can be used as well as the time study can be done.

Step 4. General analysis of all setups and choosing the first setup to analyze

To analyze the gathered data, the following analyses can be used: Pareto-Lorenz analysis, Histogram, Bar chart, Statistical analysis, Dotplot, Boxplot.

\section{Step 5. Analysis of a chosen setup}

In the fifth step we perform the SMED analysis of the chosen setup. Such an analysis can be done later for other setups as well. In this step we have to remember about team work. Operators working on a work stand have to be also the members of a team to achieve better results of the analysis and to ensure that the rules and procedures settled during the analysis will be accepted and followed by the operators in the future. During the analysis we can also use the following tools: Spaghetti diagram, Brainstorming, Benchmarking, Visualization, 5S.

\section{Step 6. Risk analysis}

During the setup process both the accessibility of procedures and the accessibility of the necessary tools and equipment are important to perform the setup in a settled time. A setup longer than planned can cause various problems that the company would like to prevent. That is why, in order to assess the risk of problems with setups, the author suggests using the assessment criteria presented in Tables 3-5. Risk can be calculated with the formula (2)

$$
R=F \cdot M \cdot P,
$$

where $F$ - error frequency, $M$ - error meaning for a setup time, $P$ - probability of finding a problem before the setup starts.

Table 3

Criteria of error frequency $(F)$.

\begin{tabular}{l|l|c|l}
\hline Frequency of error appearance & \multicolumn{2}{|c}{ Description } & \multicolumn{1}{c}{ Error frequency } \\
\hline Accidental & Error appearance is almost impossible & 1 & 1 per 100 setups or less \\
\hline Very low & A very few errors appear & 2 & 1 per 50 setups \\
\hline Low & A few errors appear & 3 & 1 per 20 setups \\
\hline Average & Errors appear from time to time & $4-6$ & 1 per 10 setups \\
\hline High & Errors repeat periodically & $7-8$ & 1 per 2 setups \\
\hline Very high & It is almost impossible to avoid an error & $9-10$ & $\begin{array}{l}\text { Error appears every time during the } \\
\text { setup }\end{array}$ \\
\hline
\end{tabular}

Table 4

Criteria of error meaning for the setup time $(M)$.

\begin{tabular}{l|l|c}
\hline \multicolumn{2}{c|}{ Error influence on the setup time } & $M$ \\
\hline Error has no influence on the setup time & Setup time will not be longer & 1 \\
\hline Error has a little influence on the setup time & $\begin{array}{l}\text { Setup time will be longer but it will not have any influence on } \\
\text { production }\end{array}$ & $2-3$ \\
\hline Error has noticeable influence on the setup time & $\begin{array}{l}\text { Setup time will be longer and it will have noticeable influence } \\
\text { on production }\end{array}$ & $4-6$ \\
\hline Error has great influence on the setup time & $\begin{array}{l}\text { Setup time will be longer and that can cause problems with } \\
\text { production planning and its realization }\end{array}$ & $7-8$ \\
\hline Error has very high influence on the setup time & $\begin{array}{l}\text { Setup time will be longer and there is a high risk of delay of } \\
\text { product delivery to a customer }\end{array}$ & $9-10$ \\
\hline
\end{tabular}


Table 5

Probability of discovering a problem before the setup starts $(P)$.

\begin{tabular}{l|l|c}
\hline Detectability & \multicolumn{1}{|c}{ Probability of discovering a problem } & $P$ \\
\hline Very high & Problem can be easily discovered before the setup starts & $1-2$ \\
\hline High & Problem can be discovered before the setup starts but it can be too late to prevent a slight delay & $3-4$ \\
\hline Average & Problem can be discovered before the setup starts but it can be too late to prevent a delay & $5-6$ \\
\hline Low & Probability of discovering problem before the setup starts is almost impossible & $7-8$ \\
\hline Very low & Problem can be discovered only during the setup & $9-10$ \\
\hline
\end{tabular}

The risk analysis can indicate such steps of a setup which can cause the risk of extending the setup time, and what in consequence, can influence the production plan realization and so on. The results of a risk analysis can be used in the next step of the proposed methodology.

\section{Step 7. Setup standardization}

Setup standardization is done to ensure repeatability of setups. Steps, tools, materials and etc., needed in a setup and specified in the setup procedure, can help to avoid problems during the setup process. The setup time has to be long enough to perform a setup without rushing that could cause mistakes. All the necessary data have to be mentioned in the procedure or delivered to be available during a setup. All the necessary tools and equipment should be indicated in the procedure and be prepared to use in a setup process. Operators need to be trained and be aware of the necessity of performing a setup solely according to the procedure.

\section{Use of the proposed methodology in the analysis of CNC turning lathe setups}

\section{Characteristics of a machine and a work stand}

The proposed methodology is implemented into the setups analysis in a company which has a machining department with 16 machines. It is worth to emphasize that this company has never improved setups before and has never done any setup analysis. The setup time was settled on the basis of the three previous setups.

To perform the analysis a CNC turning lathe was chosen. This machine was one of 16 machines found in the machining department. Each machine needed a changeover. The CNC turning lathe was chosen because of the biggest number of changeovers, which were realized on the machine (Step 1).

A work stand on which the machine is placed consists of a machine, table, tooling cabinet and shelving with devices which are used in some production operations.

A work stand is equipped, among other things, with an electronic slide caliper, electronic deep gauge, and if necessary, an operator brings other devices and tools to perform a certain production operation.

\section{Review of tasks performance on the work stand}

To identify the activities realized on the work stand $5 \mathrm{x}$ Why? method was used (Step 2). The method was used during a conversation with the machine operator who answered the questions presented in Table 6 . The table also includes the operator's answers. On the basis of the presented analysis, it can be said that an operator performs all activities concerning a setup process when the machine stops. That is why, the setup process should be analyzed carefully within the setup time because it doesn't add value to the product.

\section{Gathering and analyzing the data concerning setups on a CNC turning lathe}

Various types of setups are made on the analyzed $\mathrm{CNC}$ turning machine. First of all, the types of setups were identified. In order to do it, the data concerning setups on the analyzed CNC turning machine were registered within a month. A control sheet was prepared. The following information was registered on the control sheet: a setup date, a type of a setup, planed setup time, real setup time (Step 3).

In the Step 4 the gathered data were analyzed and the results are presented in Figs. 11-20. In Fig. 11 a run chart of the setups performed within one month on a CNC turning machine is presented. The total time of the changeovers was $\mathbf{1} 330 \mathrm{~min}$ (22 hours 10 minutes). During this month various types of setups were realized. In Fig. 12 one can see the rate of the certain setup types and the total real setup time for each type of the setups. Figure 13 presents the real setup time for each type of the setups. It can be seen that the same kind of a setup sometimes took more and sometimes less time. 
Table 6

Questions and answers from 5 x Why? Analysis for a CNC turning lathe.

\begin{tabular}{|c|c|c|}
\hline Question & & Answer \\
\hline \multicolumn{3}{|c|}{ Goal } \\
\hline $\begin{array}{l}\text { What kind of activities are } \\
\text { done on the work stand? }\end{array}$ & Bronze, brass and plastics machining & Setups \\
\hline $\begin{array}{l}\text { Why are these activities done } \\
\text { on the work stand? }\end{array}$ & It was planned & $\begin{array}{l}\text { To change tooling to move on to the next pro- } \\
\text { duction operation for another product }\end{array}$ \\
\hline $\begin{array}{l}\text { What else can be done on the } \\
\text { work stand? }\end{array}$ & $\begin{array}{l}\text { Other, new products can be manufac- } \\
\text { tured }\end{array}$ & $\begin{array}{l}\text { Other, new setups concerning a new product } \\
\text { manufacturing can be done }\end{array}$ \\
\hline \multicolumn{3}{|c|}{ Place } \\
\hline Where are the activities done? & $\begin{array}{l}\text { On the work stand with a CNC turning } \\
\text { lathe }\end{array}$ & On the work stand with a CNC turning lathe \\
\hline Why there? & It was planned & That was settled \\
\hline Where else can it be done? & On other CNC turning lathes & Only there \\
\hline \multicolumn{3}{|c|}{ Sequence } \\
\hline When is it done? & After receiving a production order & $\begin{array}{l}\text { After receiving a production order and during } \\
\text { the machine stoppage }\end{array}$ \\
\hline Why then? & $\begin{array}{l}\text { Because it is not necessary to produce } \\
\text { the product earlier }\end{array}$ & No one requires earlier actions \\
\hline When else can it be done? & $\begin{array}{l}\text { There is no possibility to produce } \\
\text { products without a production order }\end{array}$ & $\begin{array}{l}\text { Partly during the production operation of the } \\
\text { previous product }\end{array}$ \\
\hline \multicolumn{3}{|c|}{ Person } \\
\hline Who does this? & Operator & Operator \\
\hline Why this person? & $\begin{array}{l}\text { Because the operator has adequate } \\
\text { qualifications to do the job }\end{array}$ & $\begin{array}{l}\text { Because the operator has adequate qualifica- } \\
\text { tions to do the setup and no one else is assigned } \\
\text { to do it }\end{array}$ \\
\hline Who else can do it? & $\begin{array}{l}\text { Operators from other work stands with } \\
\text { CNC turning lathes }\end{array}$ & Other operators \\
\hline \multicolumn{3}{|c|}{ Means } \\
\hline How is it done? & According to the plant standards & $\begin{array}{l}\text { According to the guidelines and technical doc- } \\
\text { umentation }\end{array}$ \\
\hline Why in this manner? & $\begin{array}{l}\text { They are recognized as adequate and } \\
\text { meet the quality and safety require- } \\
\text { ments }\end{array}$ & Because it was established this way \\
\hline How else can it be done? & $\begin{array}{l}\text { On this machine only in this manner } \\
\text { because the job should be done accord- } \\
\text { ing to the procedures }\end{array}$ & $\begin{array}{l}\text { Actually, only in this manner unless a new pro- } \\
\text { cedure concerning the setup process is estab- } \\
\text { lished }\end{array}$ \\
\hline
\end{tabular}

The times of setups were planned. In a planning process setup the time was calculated on the basis of three last setups. Figure 14 presents a comparison of the planned and the real setup time for all the setups from one month. In Fig. 14 one can see that the real setup time was 13 times longer or 9 times shorter than planned. It means that the setup time planning process is not effective.

From Figs. 15 and 16, which present the real and planned setup time, it can be concluded that the most common duration of the planned and real setup time was $60 \mathrm{~min}$. Four operators worked on the analyzed work stand. In Figs. 17-20 the analysis concerning the type of setups and operators (161 and 238) is presented. There is no repeatability for operators. Most often the setup was realized by the operator 238 - that is 16 times.

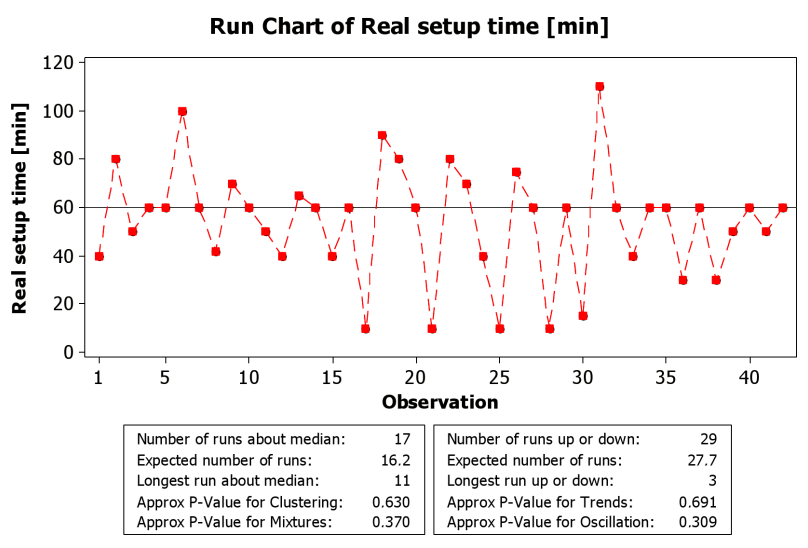

Fig. 11. Run chart of setups realized within one month on a CNC turning machine. 


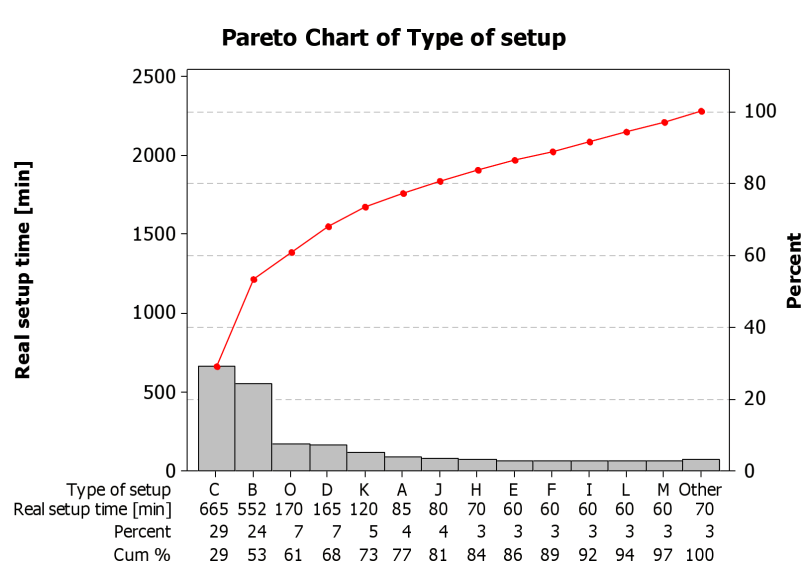

Fig. 12. Pareto diagram of setup types.

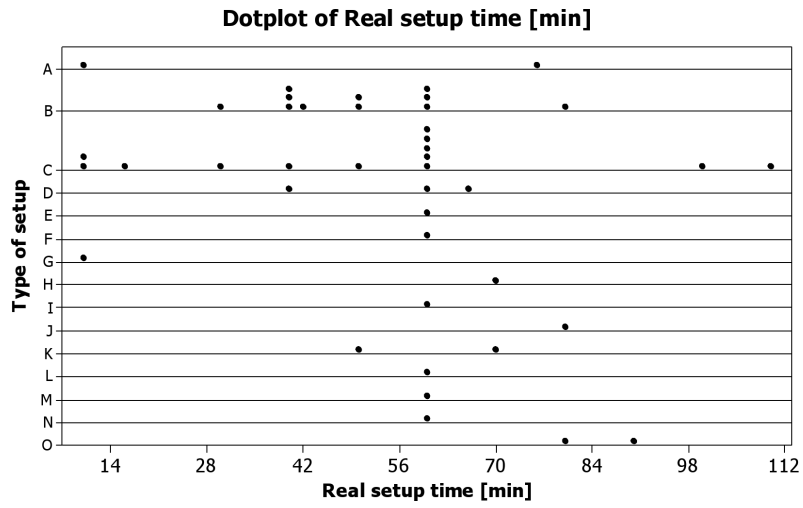

Fig. 13. Real setup times.
The setup was realized 14 times by the operator 161 and only 6 times by the operator 165 . For the type $\mathrm{C}$ and $\mathrm{B}$ setups $C h i^{2}$ analyses were made.

The hypothesis was formulated as follows: There is no difference in the setup time between operators.

In both cases $P$-value $=0$, what means that an operator has influence on the setup time.

On the basis of the analysis the following conclusions can be drawn:

- There is no standard time for each setup type. The setup time is planned based on the information on the duration of the three last setup times.

- The real setup time is different from the planned setup time.

- The longest setup time was registered for the setup type $\mathrm{C}$ and it took $110 \mathrm{~min}$.

- The setups type $\mathrm{C}$ were realized most often - 13 times.

The following reasons determine the implementation of the setup improvements:

1. There are difficulties with a setup planning process.

2. The setup time depends on an operator's efficiency and engagement.

3. There isn't one standard for each setup process.

4. The total setup time on the analyzed machine covers 22 hours 10 minutes. Knowing that for machining one product 7 minutes is needed, this means that in the time dedicated for setups additional 190 products could be machined.

These reasons convinced the management to introduce the SMED method.

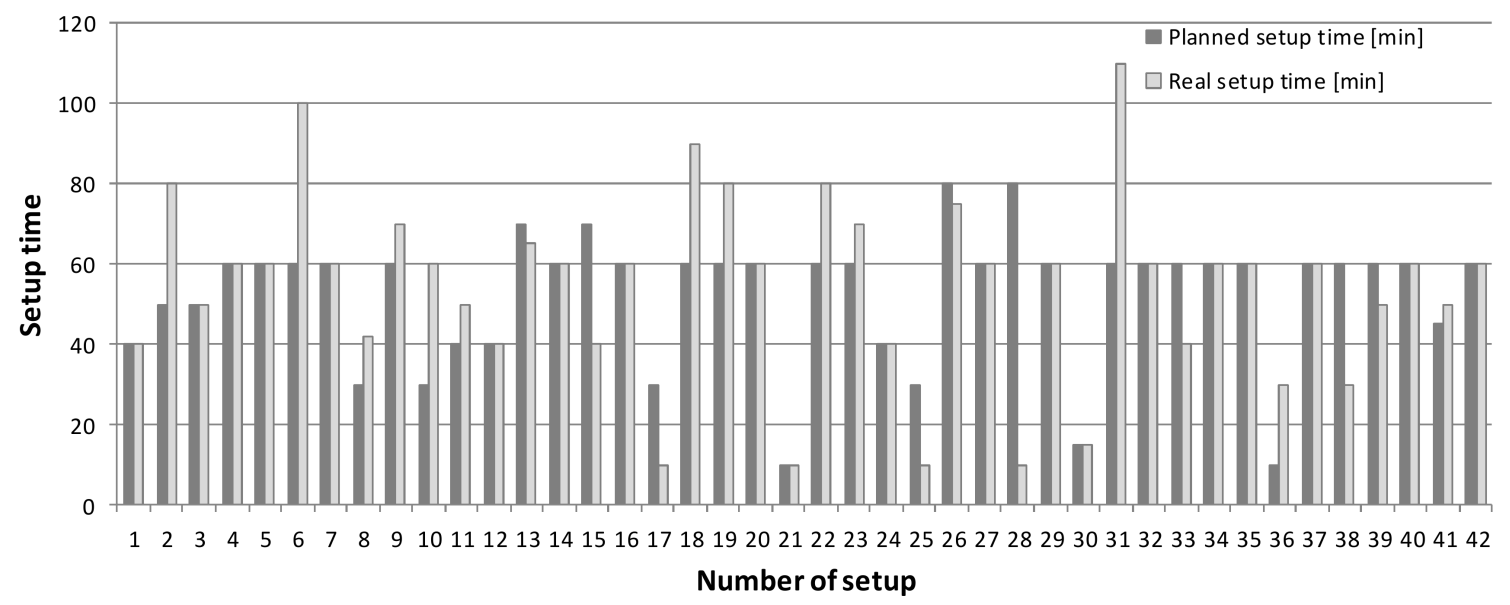

Fig. 14. Comparison of the planned and real setup time. 


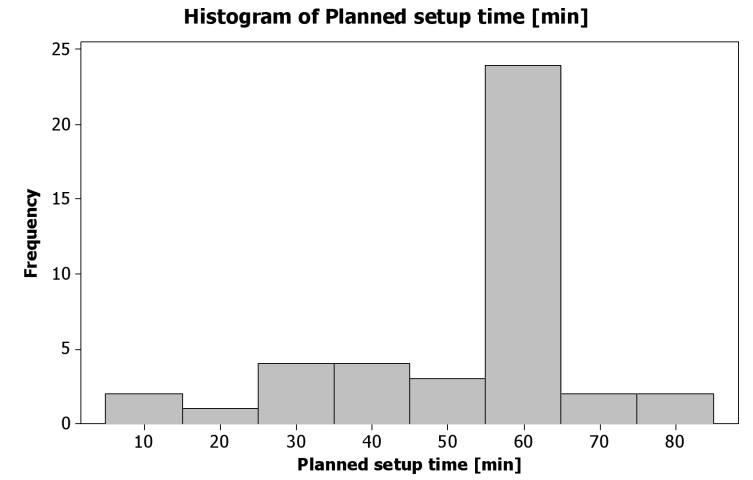

Fig. 15. Histogram for the planned setup times in one month.

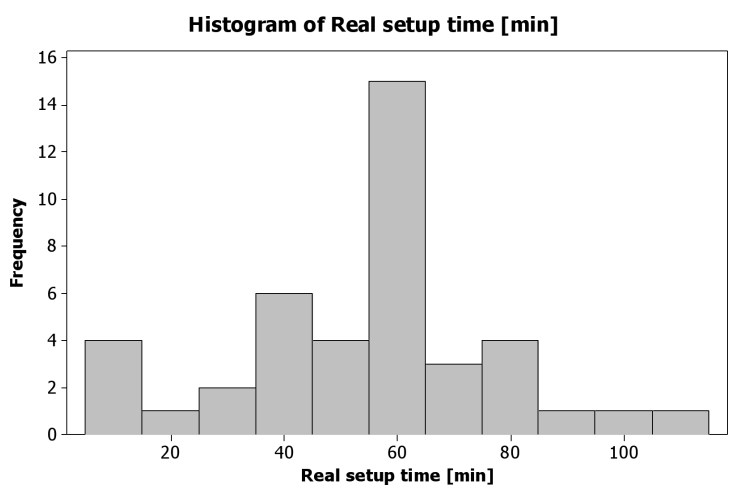

Fig. 16. Histogram for real setup times in one month.

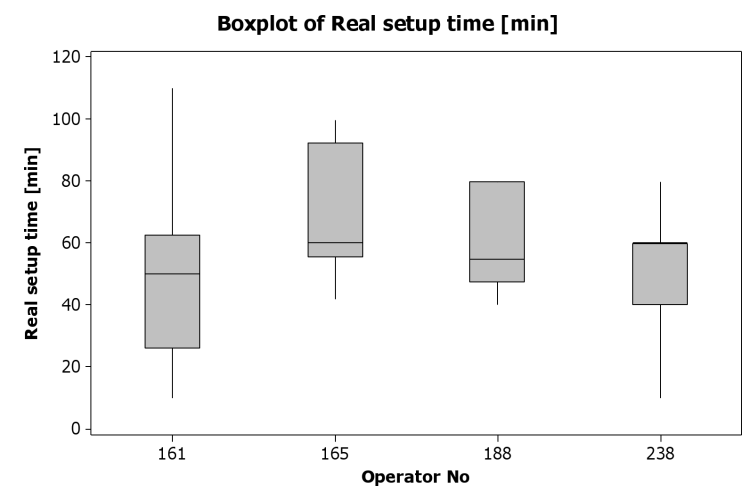

Fig. 17. Boxplot of the real setup time for operators.

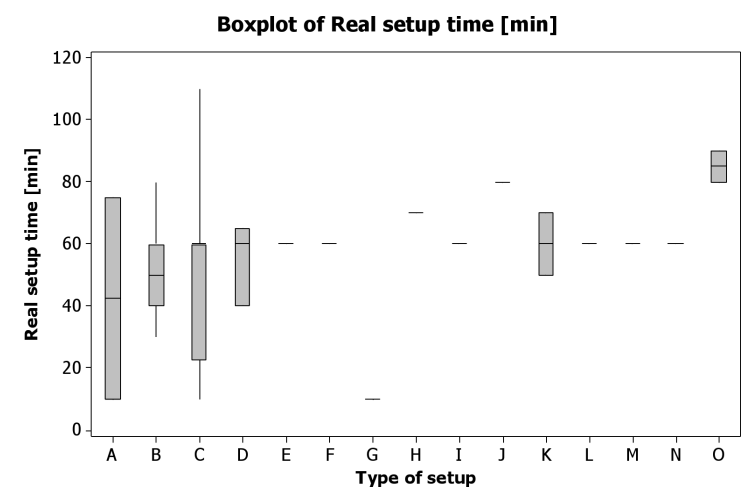

Fig. 18. Boxplot of real setup time for type of setups.

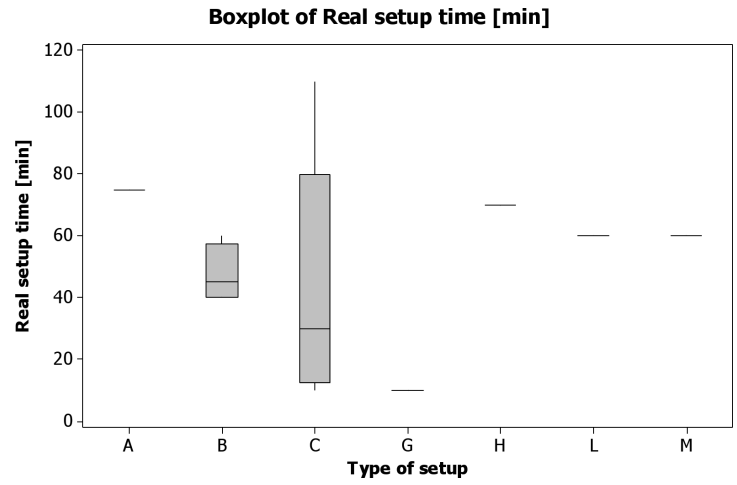

Fig. 19. Boxplot of real setup time for Operator 161

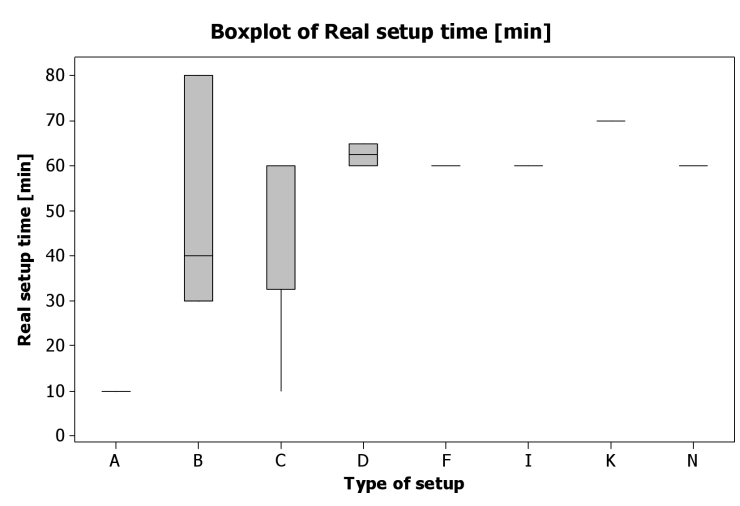

Fig. 20. Boxplot of real setup time for Operator 238.

\section{Observation of a changeover process and identification of internal and external activities}

On the basis of the analysis and the conclusions, the setup type $\mathrm{C}$ was chosen for the following analysis (step 5). The setup process was carried out on a CNC turning machine and it was recorded with a video camera. That helped to conduct a thorough analysis of the process.

According to the SMED method steps, first, the setup process was observed and next, the activities in the process were identified. After that, the activities were divided into three groups: external, internal and unnecessary. Part of the observation and analysis results are presented in Table 7 . In the table, the activities which can be external and which have to be internal are indicated.

The setup time took 1 hour 12 minutes and 4 seconds. On the basis of the information from Table 7 , it can be said that there is a possibility to shorten the setup time by excluding external activities from the setup process. It could save $3 \mathrm{~min} 37 \mathrm{~s}$. The unnecessary activities weren't identified. 
Table 7

Observation sheet - excerpt.

\begin{tabular}{c|c|c|c|c|c|c}
\hline \multicolumn{2}{c|}{$\begin{array}{c}\text { Work stand: } \\
\text { CNC turning lathe }\end{array}$} & \multicolumn{5}{c}{ Speration: } \\
\hline No & Description of an activity & Start & End & Duration $[\mathrm{s}]$ & Internal & External \\
\hline 1 & Looking for a CNC program & $00: 00$ & $01: 00$ & 60 & $\mathrm{x}$ & \\
\hline 2 & Jaws disassembly & $01: 00$ & $01: 50$ & 50 & $\mathrm{x}$ & \\
\hline 3 & Walk for a holder & $01: 50$ & $02: 12$ & 22 & & $\mathrm{x}$ \\
\hline 4 & Holder assembly & $02: 12$ & $03: 30$ & 78 & $\mathrm{x}$ & \\
\hline 5 & Disassembling screws from the jaws & $03: 30$ & $04: 20$ & 50 & $\mathrm{x}$ & \\
\hline 6 & Walk for jaws & $04: 20$ & $04: 45$ & 25 & & $\mathrm{x}$ \\
\hline 7 & Screw screws in jaws & $04: 45$ & $05: 55$ & 70 & $\mathrm{x}$ & \\
\hline$\ldots$ & $\ldots$ & $\ldots$ & $\ldots$ & $\ldots$ & $\ldots$ & $\ldots$ \\
\hline 32 & Checking the first good piece in a technical control process & $1: 06: 00$ & $1: 12: 04$ & 364 & $\mathrm{x}$ & \\
\hline
\end{tabular}

Table 8

FMEA analysis for setup process,

\begin{tabular}{|c|c|c|c|c|c|c|c|c|c|}
\hline No & $\begin{array}{l}\text { Description of an } \\
\text { activity }\end{array}$ & Potential error & Causes of the error & Results of the error & $\begin{array}{l}\text { Actual preven- } \\
\text { tive actions }\end{array}$ & $\mathrm{F}$ & $\mathrm{M}$ & $\mathrm{P}$ & $\mathrm{R}$ \\
\hline 1 & $\begin{array}{l}\text { Looking for a CNC } \\
\text { program }\end{array}$ & $\begin{array}{l}\text { There is no pro- } \\
\text { gram }\end{array}$ & $\begin{array}{l}\text { The program } \\
\text { hasn't been load- } \\
\text { ed into the system }\end{array}$ & $\begin{array}{l}\text { The CNC program } \\
\text { must be written } \\
\text { and/or loaded into } \\
\text { the system }\end{array}$ & None & 1 & 7 & 1 & 7 \\
\hline 2 & Jaws disassembling & $\begin{array}{l}\text { Spanner isn't avail- } \\
\text { able on the work } \\
\text { stand }\end{array}$ & $\begin{array}{l}\text { Someone has tak- } \\
\text { en a spanner }\end{array}$ & $\begin{array}{l}\text { Operator has to } \\
\text { look for the spanner }\end{array}$ & None & 4 & 3 & 1 & 12 \\
\hline 3 & Holder assembly & Holder doesn't fit & $\begin{array}{l}\text { Right holder isn't } \\
\text { on the work stand }\end{array}$ & $\begin{array}{l}\text { Operator has to } \\
\text { look for the holder }\end{array}$ & None & 3 & 3 & 1 & 9 \\
\hline 4 & Jaws assembly & $\begin{array}{l}\text { Jaws are assembled } \\
\text { not precisely }\end{array}$ & $\begin{array}{l}\text { Operator made a } \\
\text { mistake during the } \\
\text { jaws' assembling }\end{array}$ & $\begin{array}{l}\text { Work piece can't be } \\
\text { fixed properly }\end{array}$ & None & 3 & 3 & 1 & 9 \\
\hline 5 & Assembly of tools & $\begin{array}{l}\text { There is a lack of } \\
\text { tools on the work } \\
\text { stand }\end{array}$ & $\begin{array}{l}\text { Someone has tak- } \\
\text { en the tool }\end{array}$ & $\begin{array}{l}\text { Operator has to } \\
\text { look for the tool }\end{array}$ & $\begin{array}{l}\text { Prepared set of } \\
\text { tools for each } \\
\text { setup } 4\end{array}$ & & 3 & 1 & 12 \\
\hline 6 & $\begin{array}{l}\text { Tools } \text { description } \\
\text { and loading the } \\
\text { data concerning } \\
\text { the measurement } \\
\text { of X axis }\end{array}$ & $\begin{array}{l}\text { Wrong data are } \\
\text { loaded }\end{array}$ & $\begin{array}{l}\text { Operator's mis- } \\
\text { take }\end{array}$ & $\begin{array}{l}\text { Data must be load- } \\
\text { ed again }\end{array}$ & $\begin{array}{l}\text { Setup proce- } \\
\text { dure }\end{array}$ & 5 & 4 & 9 & 180 \\
\hline 7 & $\begin{array}{l}\text { Synchronization of } \\
\text { tools seats numbers } \\
\text { with a CNC pro- } \\
\text { gram }\end{array}$ & $\begin{array}{l}\text { Wrong data are } \\
\text { loaded }\end{array}$ & $\begin{array}{l}\text { Operator's mis- } \\
\text { take }\end{array}$ & $\begin{array}{l}\text { Data must be load- } \\
\text { ed again }\end{array}$ & $\begin{array}{l}\text { Setup proce- } \\
\text { dure }\end{array}$ & 5 & 4 & 9 & 180 \\
\hline 8 & $\begin{array}{l}\text { Simulation of an } \\
\text { operation }\end{array}$ & $\begin{array}{l}\text { Machine doesn't } \\
\text { work properly }\end{array}$ & $\begin{array}{l}\text { Wrong data were } \\
\text { loaded or tools } \\
\text { weren't assembled } \\
\text { properly }\end{array}$ & $\begin{array}{l}\text { The setup proce- } \\
\text { dure must be re- } \\
\text { peated }\end{array}$ & $\begin{array}{l}\text { Setup proce- } \\
\text { dure }\end{array}$ & 5 & 5 & 9 & 225 \\
\hline 9 & Reboring of jaws & $\begin{array}{l}\text { Problem with right } \\
\text { jaws reboring }\end{array}$ & $\begin{array}{l}\text { Little experience } \\
\text { of the operator }\end{array}$ & $\begin{array}{l}\text { Longer time of jaws } \\
\text { reboring }\end{array}$ & None & 6 & 5 & 2 & 60 \\
\hline 10 & $\begin{array}{l}\text { Measurement of a } \\
\text { reference point }\end{array}$ & $\begin{array}{l}\text { Wrong measure- } \\
\text { ment }\end{array}$ & $\begin{array}{l}\text { Little experience } \\
\text { of the operator }\end{array}$ & $\begin{array}{l}\text { Nonconforming } \\
\text { product. The setup } \\
\text { procedure must be } \\
\text { repeated }\end{array}$ & $\begin{array}{l}\text { Setup proce- } \\
\text { dure }\end{array}$ & 6 & 5 & 2 & 60 \\
\hline 11 & $\begin{array}{l}\text { Measurement of } \\
\text { tool in } \mathrm{Z} \text { axis }\end{array}$ & $\begin{array}{l}\text { Wrong measure- } \\
\text { ment }\end{array}$ & $\begin{array}{l}\text { Little experience } \\
\text { of the operator }\end{array}$ & $\begin{array}{l}\text { Nonconforming } \\
\text { product. The setup } \\
\text { procedure must be } \\
\text { repeated }\end{array}$ & $\begin{array}{l}\text { Setup proce- } \\
\text { dure }\end{array}$ & 6 & 5 & 2 & 60 \\
\hline 12 & $\begin{array}{l}\text { The second simula- } \\
\text { tion of the opera- } \\
\text { tion }\end{array}$ & $\begin{array}{l}\text { Machine doesn't } \\
\text { work properly }\end{array}$ & $\begin{array}{l}\text { Wrong data were } \\
\text { loaded }\end{array}$ & $\begin{array}{l}\text { The setup proce- } \\
\text { dure must be re- } \\
\text { peated }\end{array}$ & $\begin{array}{l}\text { Setup proce- } \\
\text { dure }\end{array}$ & 6 & 5 & 9 & 270 \\
\hline
\end{tabular}




\section{Suggestions for technical and organizational improvements}

The setup process consists of 32 activities. Six of them were related to transport of tools and they took 3 min $37 \mathrm{~s}$. These activities can be done before the setup process starts. In order to improve the setup process, a transport box with a set of tools for this type of a changeover was prepared. Besides, an extra set of screws for jaws was bought. It helped to save 7 min 3 s. Additionally, a set of simple gauge was prepared and marked as assigned to certain tools. That facilitated checking the correctness of tool clamping. It saved 8 min $10 \mathrm{~s}$.

\section{FMEA analysis of risk}

After the setup process analysis and after the elimination of some external activities, a risk analysis for the remaining activities was done (step 6). In the analysis the assessment criteria presented in Tables 3-5 were used. The results of the risk analysis are presented in Table 8. Based on the analysis, we can conclude that it is necessary to focus on the data which are loaded by operators during a setup process because the wrong data can cause problems on several steps of a setup process.

In order to prevent an operator's mistakes, it should be carefully analyzed what kind of data should be included in a setup procedure. Operators' training has to be also emphasized as well as the fact that an operator should be informed about the possible consequences of the wrong data loading. Simultaneously, the time long enough for a setup process has to be ensured so that no pressure is put on an operator.

\section{Setup process standardization}

To ensure that the setup process will be done in the same manner each time, the standard setup procedure was prepared (step 7). The procedure is accessible on the work stand. Implementing the procedure eliminates the activities related to the tools measurement as the relevant data are included in the procedure.

\section{Evaluation of SMED efficiency}

All proposals were put into practice at minimum cost. After that, the second analysis was made. Some of the identified activities as well as their duration are presented in Table 9. The setup time after SMED equals $44 \mathrm{~min} 55 \mathrm{~s}$. Thus, the standard time for the setup type $\mathrm{C}$ can be 45 min.

In order to evaluate the SMED method used during the changeover process, Spaghetti diagram was made. In the diagram the operator's movements are presented (Fig. 21). Additionally, the operator's movements were registered with a pedometer.

During the changeover the operator walked 110 meters what prolonged the setup process.

Figure 22 presents the operator's movements after the SMED analysis.

After SMED only one walk remained. It was a walk to the product quality control work stand. This can't be excluded or done on the work stand. The effects of SMED are presented in Table 10.

Table 9

Observation sheet after improvements - excerpt.

\begin{tabular}{|c|c|c|c|c|c|c|}
\hline & $\begin{array}{c}\text { Work stand: } \\
\text { CNC turning lathe }\end{array}$ & \multicolumn{5}{|c|}{$\begin{array}{c}\text { Operation: } \\
\text { Setup type C }\end{array}$} \\
\hline No & Description of activity & Start & End & Duration time $[\mathrm{s}]$ & Internal & External \\
\hline 1 & Looking for a CNC program & $00: 00$ & $00: 30$ & 30 & $\mathrm{x}$ & \\
\hline 2 & Jaws disassembly & $00: 30$ & $01: 55$ & 85 & $\mathrm{x}$ & $50 \mathrm{~s}$ \\
\hline 3 & Holder assembly & $01: 55$ & $02: 15$ & 20 & $\mathrm{x}$ & $15 \mathrm{~s}$ \\
\hline 4 & Jaws assembly & $02: 15$ & $04: 55$ & 160 & $\mathrm{x}$ & \\
\hline 5 & Assembly of tools & $04: 55$ & $08: 20$ & 205 & $\mathrm{x}$ & \\
\hline 8 & $\ldots$ & $\ldots$ & $\ldots$ & $\ldots$ & $\ldots$ & $\ldots$ \\
\hline 14 & Checking the first good piece in a technical control process & $39: 45$ & $45: 55$ & 310 & $\mathrm{x}$ & \\
\hline
\end{tabular}

Table 10

Effects of the SMED method implementation.

\begin{tabular}{c|c|c}
\hline Setup time before SMED & Setup time after SMED & Saved time \\
\hline $1 \mathrm{~h} 12 \mathrm{~min} 4 \mathrm{sec}$ & $44 \mathrm{~min} 55 \mathrm{sec}$ & $27 \mathrm{~min} 9 \mathrm{sec}$ \\
\hline $4324 \mathrm{sec}$ & $2695 \mathrm{sec}$ & $1629 \mathrm{sec}$ \\
\hline $100 \%$ & $62.33 \%$ & $37.67 \%$ \\
\hline
\end{tabular}




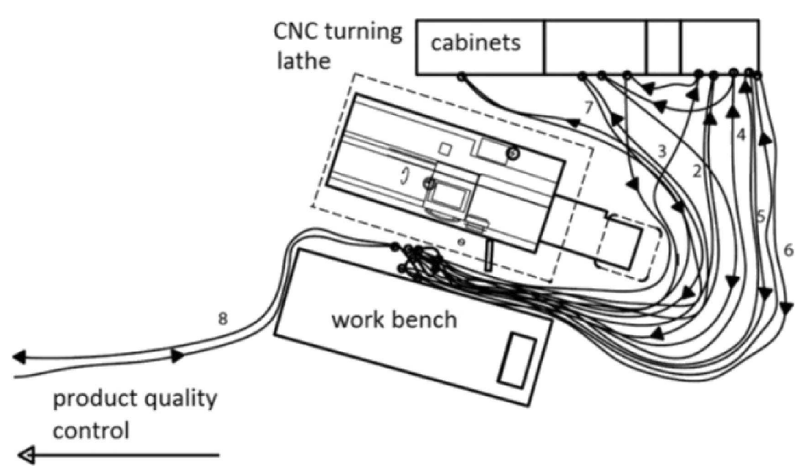

Fig. 21. Spaghetti Diagram of the operator's movements before SMED.

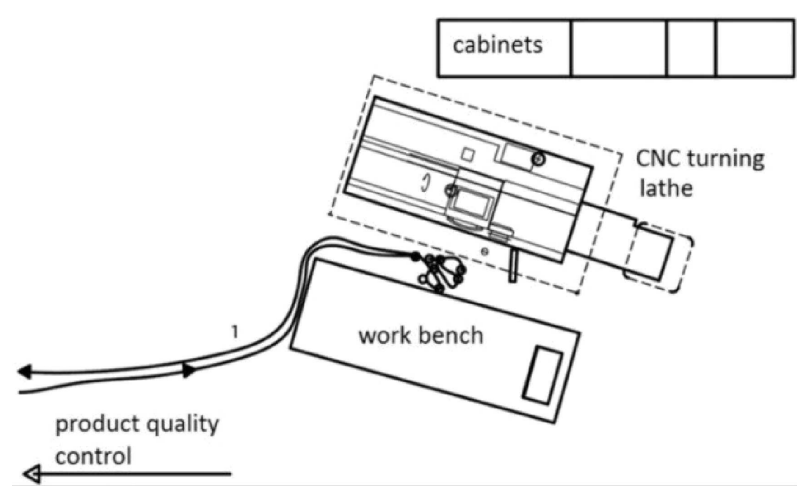

Fig. 22. Spaghetti Diagram of the operator's movements after SMED.

In addition, other indicators (3), (4) and (5) were calculated in order to assess the efficiency [25]:

a. EPZ - efficiency of the transformation of internal activities into external activities (3), where: $T_{w}-$ time of internal activities (setup time after SMED), $T_{u t}$ - saving the time of internal activities

$$
E P Z=\frac{T_{w}+T_{u t}}{T_{w}+T_{u t}+T_{z}}
$$

related to improvements, $T_{z}$ - time of external activities.

b. EUT - efficiency of improvements (4)

$$
E U Z=\frac{T_{w}}{T_{w}-T_{u t}},
$$

c. CESMED - overall efficiency of the SMED method (5)

$$
C E S A M E D=\frac{T_{w}}{T_{w}+T_{u t}+T_{z}}=E P Z \cdot E U T .
$$

For the analyzed setup process, where $T_{w}=$ $44 \mathrm{~min} 55 \mathrm{sec}=2695 \mathrm{~s}, T_{u t}=9 \min 38 \mathrm{sec}=578 \mathrm{~s}$ and $T_{z}=3 \min 37 \mathrm{sec}=217 \mathrm{~s}$, the indicators equal: $E P Z=0.94, E U T=0.82$ and $C E S M E D=0.77$.
The lower EPZ the better, because it means that the majority of internal activities were transformed into external activities. The similar situation is for $E U Z$. The lower $E U Z$ the better, because it means that the introduced improvements decreased the time of internal activities. The obtained results are not impressive, although almost $38 \%$ of the setup time is saved.

\section{Conclusions}

The methodology of a setup analysis, proposed in this paper, is primarily dedicated to the companies which are not sure if they have problems with setup processes. Since the problem is not discovered no one is willing to undertake any action.

The conducted survey shows that there are companies which do nothing to decrease the setup time. The results of the survey also prove that neither the setup frequency nor the average setup time encourage to undertake improvement actions in order to decrease setup time. During the data analysis it was discovered that the setup frequency has an impact on the setup time. On the other hand, neither the source of an operator's knowledge about the setup process nor the standards have significant influence on the setup time. The setup time depends on the SMED method efficiency and on transforming internal activities into external activities. Moreover, technical and organizational improvements can decrease the setup time to a great extent.

The proposed methodology was validated in a production company. The results of the analysis convinced the management to implement the SMED method. The SMED analysis gave almost 38\%-setup -time-saving.

FMEA analysis showed the steps of a setup process, those which are connected to a higher risk. The results of the risk analysis were taken into consideration during the preparation of the setup procedure.

\section{References}

[1] Majowicz M., Using chosen Lean manufacturing tools for setup time shortening in Zaktad Artykułów Ściernych ARMES in Nisko [in Polish], Unpublished work carried out under the direction of Dorota Stadnicka, PhD. 2011.

[2] Ohno T., Toyota Production System: Beyond LargeScale Production, Productivity Press, 1988.

[3] Cousens A., Szwejczewski M., Sweeney M., A process for managing manufacturing flexibility, 
International Journal of Operations \& Production Management, 29, 4, 357-385, 2009.

[4] Laugen B.T., Acur N., Boer H., Frick J., Best manufacturing practices: What do the best-performing companies do?, International Journal of Operations \& Production Management, 25, 2, 131-150, 2005.

[5] Shingo S., A Revolution in Manufacturing: The SMED System, Productivity Press, 1985.

[6] Hines P., Holweg M., Rich N., Learning to evolve: A review of contemporary lean thinking, International Journal of Operations \& Production Management, 24, 10, 994-1011, 2004.

[7] Moreira A.C., Single Minute Exchange of Die. A Case Study Implementation", Journal of Technology Management \& Innovation, 6, 1, 129-146, 2011.

[8] Władysiak R., Reengineering of Permanent Mould Casting with Lean Manufacturing Methods, Archives of Foundry Engineering, 7, 3, 205-212, 2007.

[9] Pacana A., Zaborowski M., Production organization with the use of the SMED method in pharmaceuticals company [in Polish, abstract in English], Zarządzanie Przedsiębiorstwem, 1, 61-69, 2009.

[10] Grzybowska K., Gajdzik B., Optimization of equipment setup process in enterprises, Metalurgija, 51, 4, 555-558, 2012.

[11] Kumar B.S., Abuthakeer S.S., Implementation of Lean Tools and Techniques in an Automotive Industry, Journal of Applied Sciences, 12, 10, 1032-1037, 2012 .

[12] Allahverdi A., Soroush H.M., The significance of reducing setup times/setup costs, European Journal of Operational Research, 187, 3, 978-984, 2008.

[13] McIntosh R.I., Culley S.J., Mileham A.R., Owen G.W., Changeover improvement: A maintenance perspective, International Journal of Production Economics, 73, 153-163, 2001.

[14] Van Goubergen D., Van Landeghem H., Rules for integrating fats changeover capabilities into new equipment design, Robotics and Computer Integrated Manufacturing, 18, 205-214, 2002.

[15] Singh B.J., Khanduja D., Design for set-ups: a step towards quick changeovers in foundries, International Journal of Sustain design, 1, 4, 402-422, 2011.
[16] Antosz K., Sęp J., Effective management of technological machines system in a production company, Management and Production Engineering Review, 1, 4, 5-12, 2010.

[17] Cakmakci M., Process improvement: performance analysis of the setup time reduction-SMED in the automobile industry, The International Journal of Advanced Manufacturing Technology, 41, 1-2, 168179, 2009.

[18] Singh B.J., Khanduja D., Risk management in complex changeovers through CFMEA: an empirical investigation, International Journal of Industrial and Systems Engineering, 10, 4, 470-494, 2012.

[19] Jagoda-Sobalak D., Knosala R., Application of de BONO'S creative thinking in the implementation of SMED on the example of the practical [in Polish, abstract in English], Zarządzanie Przedsiębiorstwem, 2, 13-21, 2011.

[20] Van Goubergen D., An Integrated Change Framework for Setup Reduction, Proceedings of the 2009 Industrial Engineering Research Conference, Miami, FL, USA, pp. 1549-1554, 2009.

[21] Cakmakci M., Karasu M.K., Set-up time reduction process and integrated predetermined tome system MTM-UAS: A study of application in a large size company of automobile industry, The International Journal of Advanced Manufacturing Technology, 33, 334-344, 2007.

[22] Trovinger S.C., Bohn R.E., Setup Time Reduction for Electronics Assembly: Combining Simple (SMED) and IT-Based Methods, Production and Operations Managmenet, 14, 2, 205-217, 2005.

[23] Bansal S., Reddy N.V., Automatic set-up planning using a neutral part data exchange format, International Journal of Computer Aided Engineering and Technology, 3, 2, 107-125, 2011.

[24] Sherali H.D., Goubergen D.V., Landeghem H.V., A quantitative approach for scheduling activities to reduce set-up in multiply machine lines, European Journal of Operational Research, 187, 1224-1237, 2008 .

[25] Zielecki W., Stadnicka D., Machine setup times shortening with use of SMED method and evolution of its efficiency, in Production Engineering, Innovations \& Technologies of the Future, Wroclaw University of Technology, Wrocław, pp. 233-240, 2011. 